DALIBOR VELOJIĆ, doktorand

Niš, 27. marta 34

UDK 355.4(497.1)"1918/1941"

\title{
NIŠKA OBLAST I MORAVSKO-VARDARSKI PRAVAC U STRATEGIJSKIM ZAMISLIMA I RATNIM PLANOVIMA JUGOSLOVENSKOG VOJNOG VRHA 1918-1941
}

\begin{abstract}
APSTRAKT: U članku se, na osnovu građe pohranjene u Vojnom arhi$v u$, posmatraju grad Niš i dolina Morave kroz ratne planove jugoslovenske vojske u periodu 1918-1941. Pored toga, dati su i delovi ratnih planova srpske vojske protiv Turske i Bugarske do 1914. godine, u kojima je niška oblast zauzimala značajno mesto.
\end{abstract}

Ključne reči: Niš, ratni planovi, vojska, Bugarska, moravsko-vardarski pravac

Posle oslobođenja od Turaka, 1878. godine, Niš je postao veoma važan strateški centar u Srbiji. Promena granica prema Turskoj, kao i snaženje novog nezavisnog suseda, Bugarske, krajem 19. veka, odredili su gradu ulogu vojnog središta pod čijom bi se kontrolom našli kako sofijski tako i pravac prema Vardarskoj dolini. Značaj Niša kao strateške raskrsnice potvrdio se i u ratovima 1912-1918. godine. Posle završetka Prvog svetskog rata, potpisivanjem mirovnih ugovora, razgraničenjima i prividnim „sređivanjem" odnosa Kraljevine SHS (Jugoslavije od 1929) sa susedima, Niš je postao vojni centar od posebnog značaja za Kraljevinu SHS. Zadatak jedinica stacioniranih u gradu i okolini bio je da osiguraju granicu prema Bugarskoj, koja je, iako sa smanjenim vojnim potencijalom i opterećena dugovima prema saveznicima, sve više ispoljavala revizionističke težnje (Bugarska je tokom čitavog međuratnog perioda insistirala na promeni odredbi mirovnog ugovora potpisanog 27. oktobra 1919. u Nejiu, slala komitske čete u Jugoslaviju i održavala aktivne veze sa Italijanima, ustašama i mađarskim revizionistima). Iskustva vlade i vojnog vrha sa Bugarskom u proteklim ratovima ukazivala su na potrebu formiranja jakog vojnog centra $u$ južnom i istočnom delu zemlje, čije bi jedinice uspele da obezbede vrlo važnu Moravsko-vardarsku dolinu i put prema Grčkoj i Egejskom moru.

Međutim, kako je nova država dobila nove zapadne granice i suočila se sa jednom velikom silom, Italijom, uloga vojnih jedinica stacioniranih $u$ 
Srbiji bila je sekundarna u odnosu na snage na zapadu kojima je pridavan značaj i kao brani od italijanske agresije, i kao faktoru stabilnosti i čuvaru reda u novooslobođenim krajevima. Jedinice u Srbiji, čija se viša komanda nalazila u Nišu, i dalje su gravitirale (tačnije jedna divizijska oblast - Moravska) prema Bugarskoj, ali sudeći po ratnim planovima i aktivnostima na polju unutrašnje politike, sređivanje prilika na zapadu, ali i severu prema Mađarskoj bilo je prioritet.

\section{Značaj Niša u ratnim planovima srpske vojske do 1914.}

Izrada prvog ratnog plana vezana je za 1898. godinu, tačnije za sednicu od 16. marta u Ministarstvu vojnom, kojom je predsedavao kralj Milan, na kojoj su razrađivane varijante za rat sa Bugarskom i Turskom. Ovaj plan je detaljno razradio načelnik štaba Aktivne vojske pukovnik Svetozar Nešić. Svi prisutni na sednici bili su složni u tome da se protiv Turske jedino može ratovati u savezu sa ostalim balkanskim državama, dok je rat sa Bugarskom Srbija mogla da podnese i sama. U operacijama protiv Turske planirana je isključivo ofanziva kako bi se onemogućilo dovlačenje svežih snaga iz Azije. Za glavni pravac prodora određena je dolina Vardara sa $\mathrm{Ku}-$ manovom i Skopljem kao najvažnijim tačkama, naročito u slučaju bugarskog napada na Tursku, koji bi najverovatnije usledio u Makedoniji. ${ }^{1} \mathrm{Iz}$ ovoga proizilazi da bi nastala prava trka prema Vardaru za zaposedanje strateški važnih tačaka. Najveći deo vojske bi, u tom slučaju, bio raspoređen na delu od Vranja (Moravska vojska 68 bataljona pešadije, 26 eskadrona konjice i 27 baterija) do Kuršumlije ( 60 bataljona pešadije, 13 eskadrona konjice i 24 baterije). U Nišu bi se nalazila Vrhovna komanda, kao i dopunske jedinice artiljerije, inžinjerije i celokupna pozadina. Zanimljivo je da u ovoj varijanti nije predviđen eventualni sukob sa Bugarima, bar ne na pravcu Sofija-Niš, pošto su za zaštitu granice određene bile slabije jedinice III poziva smeštene u Pirotu. Očigledno je do mogućeg sukoba saveznika i „razračunavanja“ moralo doći na samoj teritoriji Makedonije. ${ }^{2}$

U slučaju rata protiv Bugarske, ukoliko Srbija ne bi imala saveznika, plan je bio da se vojska drži strogo defanzivno, da bi u pogodnom slučaju prešla u napad i ugrozila Sofiju. Jasno je bilo da su Bugarima otvorene dve varijante za napad: dolinom Nišave i iz pravca Vidina preko Zaječara. Neslaganja na sednici od 16. marta 1898. bilo je oko davanja prioriteta jednom od pravaca mogućeg napada, s obzirom na opšte mišljenje prisutnih da je daleko veća verovatnoća udara iz Sofije. Mišljenje koje su, međutim, izneli ministar građevina general Jovan Atanacković i načelnik štaba Aktivne vojske

\footnotetext{
${ }^{1}$ Vojni arhiv (VA), P 2, K 3, F 1, 3/9-12. Prepis sednice od 16. marta 1898.

2 Isto, 9/1-5. Plan izrađen juna 1902. od strane pukovnika Svetozara Nešića.
} 
Niška oblast i moravsko-vardarski pravac u strategijskim zamislima i ratnim planovima $\ldots 45$

general Dimitrije Cincar-Marković nije bilo u skladu sa iskustvima iz rata 1885, ali je imalo svojih logičnih opravdanja. Naime, Bugari bi mogli neometano izvršiti koncentraciju u rejonu Vidina i napasti u pravcu Zaječara i dalja do Paraćina, čime bi se presekla komunikacija u dolini Morave i glavnini srpskih snaga ugrozila pozadina i odstupanje. Kompromisno rešenje postignuto je predlogom kralja Milana o rasporedu dela snaga u rejonu Knjaževca kako bi se moglo uspešno dejstvovati u bilo kojem od ova dva slučaja. ${ }^{3}$ Konkretan raspored snaga po ovim odlukama donet je aprila 1898. i juna 1902. Po njemu, glavnina snaga od tri divizije redovne vojske (Moravska, Dunavska i Drinska) sa brigadama II poziva bila bi grupisana u rejonima Pirota, Babušnice i Vlasine, dok bi jedna divizija (Timočka) branila Zaječar. Određene su, prema ranijoj odluci, snage (Šumadijska divizija) za pomoć jednom od dva vojišta, bazirane u rejonu Knjaževca. U Nišu bi se nalazila gradska artiljerija, inžinjerija, kao i jedinice III poziva. ${ }^{4}$

Ratni planovi protiv Turske i Bugarske rađeni posle 1902 (planovi iz 1903, 1906. kao i tri varijante vojvode Putnika rađene od 1906. do 1912) uglavnom su se oslanjali na prvobitnu zamisao sa pomenute sednice. ${ }^{5}$ Grad Niš je u njima označen kao važna tačka iz koje bi trupe bile pokrenute na front, bilo prema jugu ili istoku, zatim, kao veliki garnizon koji bi u vanrednoj situaciji mogao da smesti rezervne snage sa već oformljenim magacinskim prostorom za smeštaj hrane i municije, ali i kao sedište Vrhovne komande.

\section{Ratni planovi jugoslovenske vojske do 1938.}

Ratne planove jugoslovenske vojske ${ }^{6}$ generalno treba posmatrati u sklopu obaveza prema Maloj Antanti i Balkanskom sporazumu koji su garantovali sigurnost granica i sprečavanje vojnog jačanja država poraženih u Prvom svetskom ratu. Međutim, budući da ovi savezi nisu mogli u potpunosti zaštititi jugoslovensku teritoriju, pre svega od Italije, bilo je neophodno izvršiti ozbiljnije i sveobuhvatnije ratne pripreme. Pri izradi ratnih planova jugoslovenski generalštab je, pre svega, imao u vidu okruženje u kome se našla zemlja posle završetka rata i međunarodnog priznavanja granica,

${ }^{3}$ Isto, 3/1-8.

${ }^{4}$ Isto, 5/1. Odluka od 10. aprila 1898; Isto, 9/1. Koncentracija srpske vojske prema istočnom frontu od juna 1902.

${ }^{5}$ Isto, 17/1. Ratni plan iz 1903; Isto, 36/1. Ratni plan iz 1906; Kombinacije vojvode Radomira Putnika rađene između 1906. i 1912. u: N. Rakočević, Ratni planovi Srbije protiv Turske od vožda Karađorđa do kralja Petra, Beograd 1933, 197-224.

${ }^{6}$ O ratnim planovima jugoslovenske vojske videti: D. Tešić, Ratni planovi Vojske Kraljevine Jugoslavije 1938-1941, VIG, 1/1991, 27-55; M. Bjelajac, Vojska... 1922-1935, 206-212. 
kao i raspoloženje Italije, novog suseda na zapadu, zainteresovanog za događaje na Balkanu.

Od susednih država Jugoslavija je $\mathrm{u}$ početku jedino sa Rumunijom bila vezana savezom, dok se Grčka smatrala neutralnom do potpisivanja Balkanskog sporazuma. Glavni protivnik bila je Italija čiji je protektorat nad Albanijom situaciju učinio složenijom po Jugoslaviju u pogledu mesta glavnog napada u eventualnom ratu. Dve poražene države, Mađarska i Bugarska, predstavljale su drugorazredne sile, s obzirom na ograničenja u naoružanju koja su im propisana odlukama mirovnih ugovora. U takvoj situaciji planovi za rat sa Italijom bili su defanzivnog karaktera, predviđajući intenzivnije radove na utvrđivanju granice i unapred određene linije za odbranu. Planovi protiv Mađarske i Bugarske predviđali su ofanzivu, ulazak na neprijateljsku teritoriju i sadejstvo sa saveznicima čije je angažovanje regulisano zajedničkim vojnim konvencijama. U pogledu Mađarske situacija je bila prilično jasna, s obzirom na postojanje Male Antante i osnovni razlog njenog formiranja, dok bi u eventualnom ratu protiv Bugarske Jugoslavija mogla da računa jedino na vojnu pomoć Rumunije. Stvaranjem Male Antante kao saveza zasnovanog na bilateralnim ugovorima, ovakve odredbe unete su i u jugoslovensko-rumunski sporazum. Čehoslovačka, kao treća saveznica, ostala bi u slučaju rata sa Bugarskom samo prijateljski neutralna, što je isključivalo vojnu pomoć i aktivno učešće ove zemlje u rešavanju problema na Balkanu.

Prvi ratni planovi izrađeni su za slučaj rata sa Italijom i predviđali su u prvo vreme odbranu, a zatim ofanzivu prema reci Soči. Izrađene su tri varijante ovog ratnog plana i sve su predviđale koncentraciju većeg dela snaga prema zapadnim granicama. Prema varijantama „I1“ i „I2“ (izrađenim 1922. i 1925) glavnina vojske bi bila upotrebljena za operacije protiv Italije, dok bi manji deo obezbeđivao pravce sa severa i istoka. Prema Mađarskoj upotrebile bi se dve divizije, kao i rečna flotila, a prema Bugarskoj iz sastava III armije Vardarska divizija stacionirana u Makedoniji. Ove jedinice ujedno su bile i strategijska rezerva Vrhovne komande i mogle su po potrebi biti prebačene na zapad. Prvobitnim planom predviđeno je baziranje Bregalničke divizije u rejonu Leskovca, ali se od toga naknadno odustalo. ${ }^{7}$ Prema ovom planu stiče se utisak da su doline Morave i Vardara ostale nebranjene u slučaju bugarskog napada, što se može objasniti sumnjom u brz vojnički oporavak i spremnost ove zemlje za rat i, prema tome, sigurnošću u sposobnost manjih snaga za odbranu istočne granice. Sam nišavski pravac morale su braniti neznatne snage od dva pešadijska bataljona i dva eskadrona konjice stacioniranih u Nišu kao dopunske jedinice. Uspešna

\footnotetext{
${ }^{7}$ VA, P 17, K 17, F 1, 4, 7. Varijanta „I1“; Isto, 5, 27. Varijanta „I2“.
} 
Niška oblast i moravsko-vardarski pravac u strategijskim zamislima i ratnim planovima... 47

odbrana veze između Niša i Skoplja morala se održati do rešavanja rata na glavnom frontu. U objašnjenju generalštaba navedeno je: „Ako Bugari reše da nas napadnu, njihov bi cilj verovatno bio posedanje južnih krajeva. Prema tome, oni će najveću svoju pažnju obratiti u Južnoj Srbiji. Ali kako uspeh u Južnoj Srbiji ne bi bio dovoljno siguran bez posedanja Niša, to nije isključeno da će oni još u samom početku baciti se jednim delom snage $u$ Južnu Srbiju, a drugim ka Nišu i uopšte u dolinu Južne Morave za osiguranje brzog uspeha u Južnoj Srbiji. Prema ovome komandant (III armije - D. V.) će proučiti i pripremiti sve što treba, te da bi sa snagama, sa kojim raspolaže, mogao sa uspehom osigurati Niš i vezu sa Skopljem." ${ }^{8}$

Povećanje vojnih efektiva, formiranje V armijske oblasti, kao i poboljšanje komunikacija narednih godina na istočnom pravcu nisu doneli bitnije promene. Prema varijanti „I3“ iz 1926. granicu prema Bugarskoj je i dalje držala III armija sastavljena od Vardarske i 2. moravske divizije, koje bi se, ukoliko zatreba, mogle uputiti u sastav V armije određene za strategijsku rezervu Vrhovne komande. Vardarska divizija bila bi stacionirana u Makedoniji, dok bi 2. moravska bila na Kosovu sa štabom u Lipljanu. Zadatak ove divizije bio je dejstvo prema Albaniji, a u slučaju bugarskog ili mađarskog napada zadržao bi se u Srbiji i Makedoniji potreban broj divizija namenjenih zapadnom frontu. ${ }^{9}$ Ključne komunikacije u Srbiji bile bi branjene raspoloživim snagama do rešavanja situacije sa Italijom ili dolaska savezničkih snaga: „Prema tome, a kako su naše glavne arterije ZagrebBeograd i Beograd-Smederevo-doline Morave i Vardara po svome položaju isuviše primaknute granicama Bugarskoj i Mađarskoj, pa usled toga i vrlo osetljive i kako od njihove sigurnosti zavisi i solidnost našeg otpora na zapadu, to je se Vrhovna komanda još od početka našla pobuđena da za ove eventualnosti rezerviše izvestan, za prvi mah dovoljan deo snaga, koji bi mogao zaštititi naše granice i pomenute arterije bar dotle, dok naši saveznici Rumuni i Čehoslovaci, a eventualno i Grci ne bi bili sposobni za akciju u korist našu. "10

U ovom objašnjenju jasno se naglašava važnost komunikacija u zaleđu glavnog fronta kao bitnih pravaca za snabdevanje i opasnost od njihovog ugrožavanja sa severa i istoka. Pretpostavlja se i savezništvo sa Grčkom, ranije deklarisanom kao neutralnom, čijim interesima ne bi išlo u prilog napredovanje Bugarske ili promena stanja u Albaniji. Modifikacija ratnog plana protiv Italije izvršena je posle potpisivanja Tiranskog pakta 1926. godine, prema kojoj je veći deo snaga namenjen za operacije prema Albaniji. Dejstva prema Bugarskoj izvodile bi Moravska, Timočka i Bregalnička

\footnotetext{
${ }^{8}$ Isto, 5, 96.

${ }^{9}$ Isto, 6, 28. Varijanta „I3“.

${ }^{10}$ Isto, 6, 114.
} 
divizija, koje bi, pored toga, bile na raspolaganju III armiji u slučaju pogoršanja stanja na albanskom frontu. ${ }^{11} \mathrm{U}$ izmenjenoj verziji ovog plana iz 1928. planirane su privremeno prema Bugarskoj i Mađarskoj samo trupe rezervne vojske, koje bi vršile zaštitu i zatvaranje granica i jedna pešadijska divizija. Ove snage bi se, u slučaju potrebe, mogle pojačati divizijama koje poslednje dolaze na red za prevoženje na zapadni front (Timočka i Bregalnička divizija ili delovi III armije koji budu nepotrebni za akciju u Albaniji). ${ }^{12} \mathrm{U}$ tu svrhu naređeno je da se prema Bugarskoj preduzmu mere za utvrđivanje pojedinih važnih tačaka i graničnih prelaza u zahvatu osiguravajućih delova, a prema potrebi i za zatvaranje pravaca: Bregalničkog, Krivopalanačkog, Vlasinskog, Nišavskog i Svetonikolskog. ${ }^{13}$

Slično ovome, urađene su i varijante plana za sukob sa Bugarskom, pod pretpostavkom neutralnosti ostalih jugoslovenskih suseda. Ovde se kao povod za rat uzimaju akcije VMRO pa se, kao preventiva, predviđa okupacija bugarske teritorije do reke Strume. Primaran cilj ovog ratnog plana bio je uništenje baze Makedonskog komiteta i prekid veze sa stanovništvom od mesta Džumaja ka severu, jer je ta teritorija bilo jezgro za prebacivanje komita preko granice. Predviđena linija umnogome se poklapa sa onom sastavljenom od strane srpskog generalštaba i predstavljenom na Konferenciji $\mathrm{u}$ Versaju (memorandum generala Petra Pešića), ${ }^{14} \mathrm{~s}$ tim što bi se zaposeo i deo stare Bugarske u cilju što povoljnije linije fronta: „Sa ovim bi se načela i stara bugarska teritorija i to bi se moglo uzeti kao nezgodno obzirom na političke prilike uopšte, ali vojnički obziri to imperativno nalažu, jer bi bilo isuviše opasno ostaviti taj deo organizovane bugarske teritorije za četničku akciju, sa koje bi se ista mogla sprovoditi i razvijati čak i u slučaju najjačeg našeg osmatranja granične linije, blagodareći ustaljenim vezama i kanalima i na taj način kompromitovala našu okupaciju u oblasti na srednjoj Strumi." ${ }^{15}$

Očigledno je iz ove odluke da Bugarska nije imala nameru da suzbije akcije komita, tako da je zaposedanje teritorije naređeno bez ikakvog ustručavanja, sa jasnom porukom da bi pojačana aktivnost četa dovela do neizbežnog sukoba dve zemlje. Rizik ovakvog poduhvata bio bi veći pošto bi se Bugarska, u zavisnosti od opšte političke situacije, trudila da iz ovoga izvuče što više koristi, bilo politički, bilo oružanom akcijom. Tako bi ovakav akt bio skopčan sa velikim opasnostima, naročito za jugoslovensku državu,

${ }^{11}$ Isto, 6, 177. Varijanta „I3Ar".

${ }^{12}$ Isto, 7, 30. Varijanta „I4 Ar“.

${ }^{13}$ Isto, 7, 153.

${ }^{14}$ O Pešićevom memorandumu videti: B. Krizman, B. Hrabak, Zapisnici sa sednica delegacije Kraljevine SHS na Mirovnoj konferenciji u Parizu, 1919-1920 (dalje: Zapisnici), Beograd 1960, 313-316.

${ }^{15}$ VA, P 17, K 17, F 1, 2, 4. Varijanta „B2“. 
Niška oblast i moravsko-vardarski pravac u strategijskim zamislima i ratnim planovima ... 49

jer bi mogao poslužiti kao varnica za veći sukob, pošto Mađarska, Italija, Albanija i Austrija ne bi propustile pogodan momenat za ostvarenje svojih namera. Shodno tome, ovakav rizičan poduhvat morao bi biti izveden iznenadno, energično i sa jakim trupama sa svom žestinom jedne kaznene ekspedicije, stavljanjem Bugarske, ali i ostalih suseda pred svršen čin. Prema podacima kojima je jugoslovenski generalštab raspolagao VMRO je u kritičnoj pograničnoj zoni brojao oko 5.000 odlično uvežbanih komita, s tim što je i deo mesnog stanovništva mogao uzeti učešća u akcijama, a nije isključena mogućnost pojačanja ove mase vojnicima i starešinama iz kadra, tako da bi Makedonski komitet mogao mobilisati 30.000 ljudi nezavisno od bugarske vlade. Za ovu akciju predviđene su bile jedinice Timočke (9. pešadijski puk), Bregalničke (22. i 23. puk), Vardarske (46. i 47. puk) i Moravske divizijske oblasti (1, 3. i 16. pešadijski puk), kao i 1. konjički puk iz Niša i 7. iz Skoplja. Razumljivo je da su za ovaj poduhvat angažovane jedinice iz pograničnih divizijskih oblasti, ali bi poziv na vežbu obveznika iz najbližih rejona na kojima su trupe dislocirane isključivao brzinu i iznenađenje. Zbog toga je predviđena mobilizacija obveznika sa teritorija ostalih armijskih oblasti i dovođenje na granicu pod izgovorom izvođenja radova na železnici. Pošto su u to vreme izvođeni radovi na pruzi Veles-Carevo selo, to je mobilizacija imala opravdanja, a jedinice bile spremne za brz i iznenadan prodor u Bugarsku. ${ }^{16}$

Dalja evolucija ratnog plana protiv Bugarske uobličena je u varijanti „B3“ iz 1923. godine. U njoj se jasnije određuje saradnja sa saveznicima, konkretno Rumunijom, i raspored vojnih snaga uz granicu. Varijanta „B3“ polazi od jugoslovensko-rumunske konvencije o uzajamnoj vojnoj pomoći u slučaju bugarskog napada. Akcijom saveznika bila bi zauzeta Sofija, kao i gornji slivovi Strume i Iskra, čime bi se Bugari mogli naterati na poštovanje obaveza iz ugovora o miru. Time bi se nametnule i nove obaveze koje bi ih naterale na lojalno držanje prema susedima, pri čemu bi nameravana okupirana oblast bila držana kao garancija. Sama borbena dejstva morala bi biti izvedena u što kraćem roku kako bi se izolovale značajnije bugarske snage i sprečilo snabdevanje preko Crnog mora, što je u planu naglašeno kao velika prednost neprijatelja. Opšti stav pri izradi ove varijante bio je da će se $\mathrm{Bu}$ gari, budući primorani na rat na dva fronta, prema Rumuniji zadržati u odbrani, dok bi, naročito zbog blizine Sofije granici, odmah napali jugoslovenske snage. Kao mogući pravci bugarskog nadiranja uzeti su timočki, nišavski i pravac prema Skoplju. Napad prema Timoku i Zaječaru uslovio bi koncentraciju snaga između Balkana i Dunava. U tom bi slučaju pozadina i bok bili izloženi udaru Rumuna, tako da je napad tim pravcem odbacivan, sem u slučaju da Bugari žele da drže odvojene saveznike, što bi ih, sa druge

${ }^{16}$ Isto, 2, 6-11. 
strane, onemogućilo da odu dalje od Timoka. Napad prema Nišu bio bi završen zauzimanjem grada, a samim tim i odsecanjem Južne Srbije i otklanjanjem opasnosti po Sofiju. Najzad, time bi bugarska Vrhovna komanda dobila veću slobodu manevrisanja, pored svih moralnih i materijalnih koristi koje bi iz uspeha proisticale. Napad prema Skoplju imao bi izgleda za uspeh, naročito ako bi Bugari u početku postigli odlučnu pobedu i dali maha komitama da ugroze unutrašnjost Južne Srbije, što bi po jugoslovensku vojsku imalo štetnih posledica. Međutim, ovakva operacija mogla bi za Bugare biti opasna, jer bi joj snage sa nišavskog pravca mogle ugroziti pozadinu i preseći vezu sa Sofijom. Prema ovome, najrealnija varijanta bio bi napad glavnim snagama prema Nišu (prema proceni generalštaba 10-11 pešadijskih divizija i jedna konjička), slabijim prema Južnoj Srbiji, a najslabijim prema Timoku, tako da bi od razvoja operacija na nišavskom pravcu zavisili i sudbina rata kao i dalje akcije saveznika. Shodno tome prema Bugarskoj bi bile grupisane jedinice I (Timočka divizija, 1. konjička divizija i rečna flotila na timočkom pravcu), III (Bregalnička, Vardarska, Drinska i Zetska divizija u Makedoniji) i V armije (Moravska, Šumadijska, Kosovska, Dunavska, 2. konjička divizija i Svetonikolski odred na nišavskom pravcu). Zanimljivo je da je II armija, iako planirana kao strategijska rezerva Vrhovne komande, bila sa štabom u Nišu i divizijama razmeštenim u Beloj Palanci (Bosanska divizija), Svrljigu (Vrbaska), Nišu (Dravska) i Paraćinu (Jadranska), što je davalo još veći značaj dolini Nišave i komunikaciji prema Sofiji. $^{17}$

Dalje varijante ratnog plana protiv Bugarske (iz 1929. i 1932) razrađivale su napad ove zemlje na Rumuniju i, u tom slučaju, postupak jugoslovenske vojske. Ponovo je kao glavno vojište označena dolina Nišave i u ovom rejonu planirano je grupisanje V armije sa štabom u Pirotu čiji je zadatak bio da izvrši prodor prema Sofiji, potpomognuta jedinicama III armije iz Makedonije i Timočkom divizijom iz pravca Zaječara, i time omete koncentraciju i razvoj bugarskih snaga. ${ }^{18}$

Saglasno sa ratnim planovima Male Antante od 1930. rađene su kombinovane varijante za rat sa Bugarskom i Mađarskom. U tom slučaju, na osnovu potpisanih vojnih konvencija, Jugoslavija je morala intervenisati svim snagama predviđenim u pojedinačnim, ranije izrađenim planovima. Nova, kombinovana varijanta „B5M4“ predstavljala je nešto izmenjenu varijantu plana „B5“ i plana „M4" pošto je veći deo snaga predviđenih za dejstva protiv Mađarske i Bugarske zadržao svoje sektore za koncentraciju i pravce dejstva. Po kombinovanoj varijanti stvorena je veća strategijska rezerva od snaga iz druge linije koje bi najpre bile upotrebljene protiv Mađarske kao

\footnotetext{
${ }^{17}$ Isto, 3, 3-56. Varijanta „B3“.

${ }^{18}$ VA, P 17, K 19, F 1, 2-8. Varijanta „B5“.
} 
Niška oblast i moravsko-vardarski pravac u strategijskim zamislima i ratnim planovima ... 51

opasnijeg neprijatelja. Sa ovom osnovnom idejom plana nije se slagao generalštab, budući da je za Jugoslaviju i Rumuniju Bugarska predstavljala svakako opasnijeg neprijatelja koji je imao gotovo jednak broj divizija kao i Mađarska, ali kraći front i manje neprijatelja. Pored toga, Bugarska je imala daleko povoljnije uslove za odbranu granica, kao i razvijenu komitsku aktivnost u pozadini neprijatelja, što je moglo usporiti koncentraciju. U izveštaju povodom izrade plana stoji: „Za Bugarsku je situacija povoljna utoliko, što je zaštićena moćnim granicama (Dunav na severu, Stara planina, Osogovska planina, Maleš i Belasica planina na zapadu) i što u unutrašnjosti ima odbrambeni ugao od velikog prirodnog značaja koji sklapaju barijera Balkana prema Rumuniji i zapadni ogranci Balkana i planinski masivi Vitoša i Rodope prema Jugoslaviji. Prirodan značaj ovog zemljišta povećava se još i stalnim utvrđenjima koja postoje na zapadnoj granici i utvrđivanjem (organizacijom) prelaza, koje će sigurno preduzeti prvog dana konflikta izazvatog sa njene strane. “19

Međutim, obziri prema Čehoslovačkoj i osnovna ideja saveza isticali su prioritet intervencije protiv Mađarske, tako da bi se u prvoj fazi rata, na osnovu plana, prema Bugarima stajalo u defanzivi. U tom slučaju bi jedinice III armije zaposele južni deo granice sa Bugarskom sa dve divizije (Bregalničkom sa štabom u Kočanima i Vardarskom sa štabom u Krivoj Palanci) i Bosiljgradskim odredom. Nišavski pravac štitila bi $\mathrm{V}$ armija sa štabom u Pirotu sa 2. konjičkom divizijom (Bela Palanka), 1. moravskom (selo Krupac), Šumadijskom (selo Sukovo), Drinskom divizijom (Sopot) kao armijskom rezervom i Vlasinskim odredom. Severni deo fronta štitila bi II armija sa štabom u Zaječaru i 2. moravskom (Knjaževac) i Timočkom divizijom (Zaječar). Kao strategijska rezerva Vrhovne komande bila je predviđena Kosovska divizija sa štabom u Leskovcu, dok bi se u Nišu nalazili 1. vazduhoplovna brigada i 2 . vazduhoplovni izviđački puk. Jedinice II armije su pored zaštite fronta i održavanja veze sa Rumunima imale zadatak demonstrativnog napada u pravcu Belogradčika kako bi privukle pažnju dela bugarskih snaga namenjenih za operacije na nišavskom pravcu. ${ }^{20} \mathrm{Iz}$ ovakvog rasporeda divizija jasno je da se u saglasnosti sa prethodnim varijantama plana za rat protiv Bugarske najveća pažnja poklanjala zaštiti doline Nišave jer bi eventualnim zauzimanjem Niša bile odsečene jedinice u Makedoniji, a neprijatelju date velike mogućnosti za manevrisanje.

Nova varijanta ovog plana iz 1935. već je predviđala savez sa Turskom i naklonost Grčke proizašle iz Balkanskog pakta, tako da je sa granice povučena II armija dok su ostale snage zadržale ranije položaje. Prema proceni, Bugarska je mogla za rat mobilisati 20 pešadijskih i 2 konjičke divizije,

\footnotetext{
${ }^{19}$ VA, P 17, K 18, F 1, 2, 2. Dodatak varijanti „B5M4“.

${ }^{20}$ Isto, 2,11.
} 
kao i 70-80 bataljona rezervne vojske. Kada bi te snage rasporedila prema neprijateljima, protiv Jugoslavije bi mogla upotrebiti šest pešadijskih i jednu konjičku diviziju. Međutim, i pored redukovanih snaga u početnoj fazi nije dolazila u obzir ofanziva dok se ne reši stanje na severu: „Bugarska, po svojoj blizini glavnim komunikacijama koje vezuju severnu i južnu Srbiju, a sposobna i umešna u upotrebi manjih, četničkih jedinica za dejstvo u dubini naše teritorije, može dosta lako i brzo da dovede $u$ pitanje izvršenje naše koncentracije a docnije i manevrovanje. Izložene opasnosti otkloniće se ako protiv Bugarske u prvo vreme ostavimo dovoljno snaga za defanzivu, a protiv Mađarske, kao opasnije, sa našim saveznicima dejstvovaćemo ofanzivno. Ovo sa razloga što nam naši saveznici mogu pružiti protiv Mađarske najefikasniju pomoć a koncentričnim i energičnim dejstvom naših, čehoslovačkih i rumunskih snaga može se najlakše i najbrže Mađarska ostaviti van opasnosti.“" ${ }^{21}$ Očigledno da napad u pravcu Sofije nije planiran zbog aktivnosti komitskih četa i sumnjivog držanja stanovništva što bi ugrozilo pozadinu III i $\mathrm{V}$ armije i time dovelo u opasnost komunikacije u dolinama Morave i Vardara.

Pored ovih, kombinovani ratni planovi izrađivani su za istovremeni sukob sa svim susednim državama, sem Rumunije i Grčke. U tom slučaju bi Italija imala mogućnosti udara iz dva pravca od kojih je osetljiviji onaj iz Albanije, čime bi se dovela u opasnost veza sa Makedonijom: „Obzirom na blizini Albanije i Bugarske i mogućnost da one istovremenom akcijom ka Kosovu i Skoplju relativno brzo odvoje Južnu Srbiju od ostatka državne teritorije ili nas prinude na odbranu u visini Skoplja i Kosova nameće nam se potreba da odmah nešto radimo u cilju otklanjanja ove opasnosti. Imajući u vidu da je Albanija slabija i da treba iskoristiti njenu slabost pre nego što joj Italijani budu mogli da pruže ozbiljnu pomoć, moramo odmah napasti Albaniju, tući je, onemogućiti vezu sa Bugarskom i osigurati veze preko Kosova sa ostatkom teritorije ako bi Bugari za to vreme ugrozili ili prekinuli veze dolinom Morave. Da li će se potom napasti Italija ili Bugarska zavisi od opšteg stanja na ratištu. Po pravcu i izloženosti naših komunikacija na kojima leži sva težina našeg rada, izgleda da bi trebalo napasti prvo Bugare, u vezi sa Rumunijom, pa najzad Italijane.“" ${ }^{“ 2}$ Ovaj plan predviđa defanzivna dejstva prema svim neprijateljima i oslonac na saveznike Rumuniju i Čehoslovačku koje bi imale zadatak da izvedu rešavajući udar. U drugoj fazi rata jugoslovenska vojska bi bila sposobna za ofanzivu i to najpre protiv Mađarske jer je komunikacija Beograd-Zagreb postavljena kao prioritet vezi sa Skopljem: „Pitanje sigurnosti naših veza sa morem i preko mora u ovakvom slučaju ne bi igralo presudnu ulogu u pogledu izbora neprijatelja na koga bi trebalo upraviti prve akcije, jer stvarno ova sigurnost ležaće u rukama naših

\footnotetext{
${ }^{21}$ VA, P 17, K 19, F 1, 3, 4. Varijanta „B5M4“ iz 1935.

${ }^{22}$ VA, P 17, K 18, F 1, 1, 20. Varijanta „I7M6ArB7“.
} 
Niška oblast i moravsko-vardarski pravac u strategijskim zamislima i ratnim planovima ... 53

velikih saveznika i ona će se moći održati preko Rumunije, ako bi bila ugrožena na Solun, dok se ne dođe do rešenja. U pogledu veze i slobode komunikacija između Beograda i Zagreba, kao i Beograda i Niša, a eventualno i Skoplja, predstavlja pitanje kapitalne važnosti jer će od toga zavisiti mogućnost našeg manevrisanja po unutrašnjim operacijskim pravcima iz centralnog položaja, naročito je važan Beograd-Zagreb zbog svoje dužine, otvorenosti i brzine sa kojom Mađari mogu biti gotovi. Stoga izlazi da u ovom slučaju prvo rešenje treba tražiti prema Mađarima i njih prvo tući, pa onda težište preneti protiv Bugara i najzad okrenuti snage protiv Italijana." ${ }^{33}$

Sve varijante u kojima su jednu zaraćenu stranu činili revizionistički susedi Jugoslavije na čelu sa Italijom (1934. izrađena je i varijanta „I7M6ArB7Au“ ili plan „D“ koji je predviđao učešće Austrije u ratu) nametale su upornu odbranu granica i rešavanje rata na frontovima saveznika. Zanimljivo je da je u tom slučaju najpre trebalo rešiti sukob sa Mađarskom i Bugarskom i najzad sa Italijom. Pre svega, na to je uticala važnost komunikacija od Beograda prema Zagrebu i Skoplju neophodnih za manevrisanje i blagovremeno snabdevanje jedinica. Zatim se velika pažnja polagala na reakciju velikih sila, naročito Francuske, za koju se pretpostavljalo da će Italiji objaviti rat i vezati za sebe jedan deo italijanskih efektiva, što bi olakšalo odbranu severnog fronta. ${ }^{24} \mathrm{U}$ ovim slučajevima znatno su redukovane snage na granici sa Bugarskom, naročito za zatvaranje doline Nišave kao glavnog pravca prodora sa istoka, što je nosilo opasnost za prekid veza i ugrožavanje pozadine čitave vojske. Prekretnicu u izradi varijanti ratnih planova protiv Bugarske donela je 1937. godina i potpisivanje Pakta o večnom prijateljstvu. Izmene koje su uslovljene rezervisanim stavom u odnosu na Bugarsku, kao verolomnog suseda, prenete su i na sve kasnije planove do 1941. godine. U novoj varijanti „I8M7Ar1Au1B8“ iz 1937, grupisanje snaga prema Bugarskoj, tačnije V armije, izvršilo bi se kao i u ranijim slučajevima, s tim što se ovaj raspored na prigraničnoj prostoriji zauzima tek posle naređenja koje će se u datom trenutku izdati Vrhovna komanda. Do tada će sve trupe rezervne vojske za zaštitu granice zauzeti predviđen raspored, a svi delovi V armije ostaju u svojim mobilizacijskim mestima. ${ }^{25}$

\section{Ratni planovi 1938-1941}

Glavna izmena u ratnim planovima posle 1938. odnosila se na prisustvo Nemačke koja je anšlusom postala novi jugoslovenski sused, daleko opasniji od ostalih. Prva varijanta izrađena te godine nosila je oznaku

\footnotetext{
${ }^{23}$ Isto, $1,180$.

${ }^{24}$ Isto, 3, 3-28. Varijanta „I7M6ArB7Au“ ili plan „D“.

${ }^{25}$ VA, P 17, K 101, F 1, 5, 234. Varijanta „I8M7Ar1Au1B8“.
} 
„NM8I9Ar2B9“ (varijanta „D8“ osnovnog plana „D“) i predviđala je Nemačku za glavnog neprijatelja koji će napasti iz pravca Austrije. Što se Italije tiče, postojala je verovatnoća da će biti na jugoslovenskoj strani posle potpisivanja ugovora iz 1937, ali i mešanja Nemačke u italijansku interesnu sferu pripajanjem Austrije. U svakom slučaju prema Italiji je trebalo postupati oprezno i predvideti operacije protiv nje u slučaju sukoba. Kao i ranijih godina računalo se na pomoć Francuske i vezivanje većeg broja nemačkih i italijanskih divizija na zapadu. Mađarska i Bugarska su označene kao protivnice, ali se računalo na savezništvo Čehoslovačke, Rumunije i Turske, proisteklo iz prethodnih sporazuma. U tim okolnostima Bugarska bi bila izolovana od svojih saveznika i naizgled predstavljala lakog protivnika. Međutim, jugoslovenski generalštab je imao na umu ukidanje odredaba mirovnog ugovora koje su se odnosile na ograničenje naoružanja i opravdano strahovao posle podataka o naglom povećanju bugarskih vojnih efektiva na 14 divizija. Veoma nepovoljna situacija nagnala je generalštab da na bilo koji način stvori momentalnu nadmoćnost nad pojedinim neprijateljima $(\mathrm{u}$ prvom redu Mađarskoj i Bugarskoj) u cilju brzog rešavanja sukoba na istočnom i severnom frontu. U prvom redu neophodno je bilo koristiti se brzinom u radu i iskoristiti vreme dok neprijateljske snage nisu dostigle maksimalnu jačinu. Ova ofanziva se prevashodno odnosila na Mađarsku, dok bi se prema ostalim susedima uglavnom branilo, iako je verovatno da bi se Bugarska, uprkos paktu, vrlo brzo izjasnila i sprovela mobilizaciju. Predviđeno je bilo izvođenje radova na utvrđivanju, jer su pojedini frontovi morali biti oslabljeni usled nedostatka snaga. U pogledu fortifikacije bilo je najvažnije severozapadno ratište, pošto je tu i najduže planirana defanziva. ${ }^{26}$

$\mathrm{Na}$ istoku je Bugarska, po svom geografskom položaju, bila u mogućnosti da ukoči slobodu rada i manevrisanja, vezivanjem jačih jugoslovenskih snaga i ugrožavanjem saobraćajne linije u dolinama Morave i Vardara. Ipak, same zemljišne karakteristike, dosta spora mobilizacija i koncentracija bugarske vojske, kao i odbrambene mere preduzete sa jugoslovenske strane, mogle su postići da ta opasnost, bar za prvo vreme, ne bude velika niti sudbonosna za dalji rad. Ovo je naročito bilo ostvarivo ako protiv sebe Bugarska ima Rumuniju i Tursku i defanzivno držanje prema njoj ne bi dalo nikakve rezultate. Zbog toga je bilo potrebno preduzeti ofanzivu da bi se opasnost otklonila, jer bi oklevanje kasnije otežalo situaciju i manevrisanje po unutrašnjim operativnim pravcima. Verovatnoća je da bi Bugarska preduzela napad prema Pirotu i Vlasini do izlaska na pogodnu liniju koja bi joj omogućila uspešniju odbranu Sofije. Pretpostavlja se da bi zaustavljanje na ovoj liniji usledilo zbog odlaska glavnih snaga na front prema Rumunima i

${ }^{26}$ VA, P 17, K 102, F 1, 1, 13. Varijanta „NM8I9Ar2B9“. 
Niška oblast i moravsko-vardarski pravac u strategijskim zamislima i ratnim planovima ... 55

Turcima. U Makedoniji bi Bugari samo potpomogli albansku ofanzivu upućenu ka Skoplju. Međutim, ukoliko Bugarska na početku rata objavi neutralnost, ni u kom slučaju se ne sme izazivati, naročito iz obzira prema Paktu o večnom prijateljstvu, ali se granice ne smeju ostaviti nezaštićene. U tom slučaju snage treba rasporediti u dolinama Morave, Nišave i Vardara spremne da zauzmu raspored čim bi njeno držanje postalo sumnjivo. Snage određene za rat na istoku bile bi iz sastava $\mathrm{V}$ armije (štab i armijski delovi u Nišu): Timočka divizija (Zaječar), 1. moravska (Pirot) i Vlasinski odred. Ove trupe bile bi potpomognute monitorima iz sastava rečne flotile sa štabom u Prahovu. U Makedoniji bi se nalazila jedino Vardarska divizija, dok bi ostale jedinice III armijske oblasti držale front prema Albaniji. U ovom slučaju strategijska rezerva, jačine 7 divizija, bila bi smeštena je na teritoriji Slovenije i Hrvatske i nije predviđena njena upotreba na istočnom frontu. ${ }^{27}$

Nešto izmenjena varijanta ovog plana predviđala je sigurno savezništvo Nemačke i Italije, tako da je V armijska oblast imala Krajinsku diviziju smeštenu u Zaječaru, Moravsku u Pirotu (u slučaju da Bugarska odmah stupi u rat), ili u Niškoj Banji (u slučaju početne neutralnosti) i 2. odred (Vlasinski) u rejonu Bosiljgrada ili Vladičinog Hana. U Makedoniji bi dejstvovala Vardarska divizija (Kumanovo) iz sastava III armijske oblasti. I u ovom slučaju strategijska rezerva bila bi koncentrisana na severu i zapadu zemlje. ${ }^{28}$

Do promene ratnih planova došlo je 1939. godine posle komadanja Čehoslovačke, pošto je Mala Antanta prestala da postoji, a Jugoslavija izgubila važnog saveznika u odnosima sa Mađarskom. Novi plan „INMArB“ ili "O" predviđao je savezništvo Rumunije i Turske i blagonaklonu neutralnost Grčke, koja je izbegavala na sve načine ulaženje u konflikt sa Nemačkom i Italijom. Jedino se računalo na njenu pomoć u dopremanju materijala iz solunske luke. Postojala je verovatnoća ulaska i Grčke u rat, ali isključivo ukoliko Mađarska, Bugarska i Albanija napadnu pre Nemačke i Italije. U odnosu na Bugarsku generalštab je izneo da nju vezuju odredbe pakta, ali je na osnovu iskustava u prethodnom ratu nalagana opreznost. Navodi se da su se Bugari, osetivši prestiž Nemačke u Evropi, okrenuli prema njoj i počeli naoružavati iz nemačkih fabrika oružja, očekujući pogodan momenat za pokretanje pitanja revizije granica: „Tako da Bugarska pokazuje jasnu nameru da oružanom snagom ostvari težnje za povraćaj izgubljenih teritorija. Svi su izgledi, prema tome, da će Bugari biti na nemačkoj strani uz koju jedino mogu da ostvare ciljeve. Bugarska će verovatno prvo napasti Rumuniju i Grčku i tu pokrenuti pitanje revizije granica, dok će se prema nama ponašati prijateljski. “29

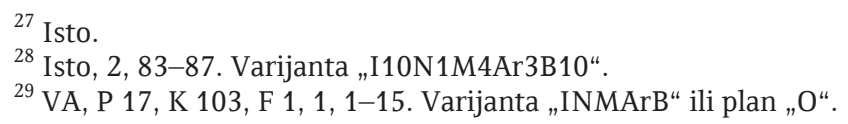


Neophodno je navesti i stav generalštaba o okupaciji dela bugarske teritorije koja je predviđana u ranijim planovima, a čiji bi povod bili upadi komita na jugoslovensku teritoriju. U predlogu sačinjenom Ministarstvu vojske i mornarice navodi se da je akcija VMRO prestala, a odnosi dve zemlje se produbljuju u duhu Pakta o večnom prijateljstvu i dopunjuju čvrstom organizacijom Balkanskog pakta: „Pa i u slučaju, kada naša teritorija prema Bugarskoj ne bi bila zaštićena ovako povoljnim političkim odnosima, već bi i nadalje bila izložena komitskoj akciji kao i ranije, Glavni đeneralštab nalazi, da mi ne bi mogli ni tada preduzeti oružanu akciju protivu $\mathrm{Bu}-$ garske na način predviđen naređenjem gospodina ministra vojske i mornarice Str. Pov. Đ. Br. 960/30, jer Bugarska nije više pod obavezama ugovora o miru i vojnički slaba, kao što je to bilo pre osam godina. Naprotiv, njena vojska se ubrzano oruža i naglo razvija tako da sada već predstavlja snagu sa kojom se mora ozbiljno računati. Zbog toga svaka naša oružana akcija protivu Bugarske i kada bi postojali razlozi, da se preduzme u ma kom vidu i obimu, dovela bi sigurno dao rata sa Bugarskom, ili do intervencije velikih sila, koje bi ovakvu akciju sprečile. “30 Prema tome, generalštab je bio protiv bilo kakvih preventivnih akcija protiv Bugarske, što je njoj davalo pravo inicijative u eventualnom ratu.

Pretpostavljalo se da bi za izvršenje koncentracije Bugarska mogla iskoristiti dve železničke pruge čiji je kapacitet 25 vozova dnevno, tako da bi zaključno sa desetim danom mobilizacije mogla dovesti dve divizije na jugoslovensku granicu sa još tri koje bi se mobilisale u pograničnim delovima. I u ovom planu predviđa se najpre obračun sa Mađarskom, a zatim svim raspoloživim snagama preduzimanje napada na Bugarsku kako bi se onemogućilo ugrožavanje ratne industrije u Šumadiji, ali i komunikacije prema Solunu, naročito ako je u rat uključena i Albanija: „Velika osetljivost istočnog fronta proističe iz njegove blizine ka dolini Zapadne Morave koja predstavlja našu glavnu ratnu industrijsku oblast, te bi Bugari upadom $u$ pravcu Zapadne Morave u stvari zaboli nož u srce našeg ratnog organizma lišavajući našu vojsku sredstava za dalje vođenje borbe... Suviše oslabiti snagu na istočnom frontu bilo bi vrlo opasno, jer bi neprijatelj, po brzom ovlađivanju industrijskom oblašću u dolini Zapadne Morave, uništio industrijske instalacije koje se ne bi mogle brzo obnoviti ni posle izbacivanja bugarskih snaga iz te oblasti. Ova opasnost unekoliko je ublažena eventualnom pomoći naših saveznika iz Balkanskog sporazuma. “31 Držanje Bugarske i pravci njenih dejstava u eventualnom ratu bili su predmet nagađanja i među saveznicima. Pripremiti se za sve moguće varijante zahtevalo je odva-

${ }^{30}$ VA, P 17, K 161, F 1, 32,3. Predlog Glavnog generalštaba Ministarstvu vojske i mornarice Str. Pov. Đ. O. Br. 1029 od 26. juna 1939.

${ }^{31}$ VA, P 17, K 103, F1, 1,20. 
Niška oblast i moravsko-vardarski pravac u strategijskim zamislima i ratnim planovima $\ldots 57$

janje priličnog broja divizija i slabljenje drugih frontova. Kalkulisalo se i sa ulaskom Grčke u rat, s obzirom na to da bi se zahtevi za reviziju granica odnosili i na njenu teritoriju. Jugoslovenski generalštab je za slučaj rata predviđao najoptimalniju varijantu bugarskog dejstva u pravcu Niša i Zaječara, na severu, i Skoplja na jugu zemlje: „Što se tiče Bugarske, najverovatnije je da će se ona držati u početku prividno neutralno čekajući rezultate nemačko-mađarskih odnosno italijansko-nemačko-mađarskih dejstava protiv nas. Čim oseti našu slabost, napašće nas u težnji da nam prekine vezu sa Solunom i da dejstvom ka Skoplju ovlada Južnom Srbijom, a dejstvom preko Niša, Knjaževca i Zaječara izbije u zaplavu Južne, Zapadne i Velike Morave i ovlada srcem Srbije. Što je najgore za ovakav slučaj, Grčka nije u savezničkoj obavezi, te će Bugarske moći da uputi za dejstvo protiv nas polovinu svoje snage (8-10 divizija), ostavljajući drugu polovinu protiv Rumunije i Turske. “" ${ }^{32}$ U ovom slučaju bugarskoj vojsci sigurno neće pretiti opasnost od Rumunije, koja bi bila angažovana na zapadu, niti od Turske, pošto je težište Bugarske (sofijsko-plovdivska oblast) udaljeno od turske granice, tako da bi bilo verovatno da prva na udaru bude Jugoslavija. Tada bi se jedan deo strategijske rezerve morao odvojiti za istočni front što bi išlo na štetu dravskom vojištu, kao glavnom. Preventivne mere koje generalštab predlaže su usavršavanje saobraćajne mreže, osposobljavanje vojske za brz transport i manevar po unutrašnjim pravcima, forsiranje radova na utvrđivanju granica, naročito severoistočne, dovođenje broja divizija na planiranih 35, a predviđena je i živa diplomatska aktivnost kako bi se Grčka ubedila na vojnu pomoć u svakom slučaju.

Ovaj plan nije doneo bitnijih izmena u pogledu rasporeda snaga, osim što je najavio odvajanje dela strategijske rezerve i slanje na istok $\mathrm{u}$ slučaju potrebe. Naredna varijanta „I2N2M2B2" ili plan „P“ iz 1940. godine, predviđa ojačanje fronta prema severnoj granici sa Bugarskom i podelu strategijske rezerve Vrhovne komande na severnu, severozapadnu i jugoistočnu grupu. Prema ovom planu V armija bi u svom sastavu imala Krajinsku (Zaječar), Topličku (Pirot) i 2. konjičku diviziju (okolina Pirota) i dva odreda Vlasinski (Vlasina) i Svetonikolski (Kalna), dok bi se u jugoistočnoj grupi strategijske rezerve nalazile Moravska (Leskovac), Timočka (Niška Banja) i Šumadijska divizija (u rejonima Kragujevca i Paraćina). ${ }^{33}$ Predviđen raspored jedinica odgovarao je ideji o početnoj bugarskoj neutralnosti, budući da su većinom bile razmeštene na svojim mirnodopskim teritorijama što je i bila namera kako se ne bi izazvao neprijatelj pokretima prema granici.

Za kasnije ratne planove izrađivane do početka Aprilskog rata karakteristična je prvi put zamisao o povlačenju prema Grčkoj i spajanju sa

\footnotetext{
${ }^{32}$ Isto, 23.

${ }^{33}$ Isto, 2. Varijanta „I2N2M2B2“ ili plan „P“.
} 
saveznicima. Plan „S“ (severni front), koji je u proleće 1940. potpisao načelnik generalštaba general Dušan Simović, predviđao je rat protiv Nemačke, Mađarske i Italije, računajući na podršku Francuske i Engleske. U ovom slučaju namera je bila da se najveći deo snaga uputi na severozapadno ratište, s tim što bi prvu liniju fronta poselo $40 \%$ trupa dok bi ostalih $60 \%$ bilo u strategijskoj rezervi. Jedinice iz rezerve bi se mobilisale tajno i prebacivane bi bile na ugroženi deo fronta tek posle početka neprijateljskih operacija i njihov zadatak je bio odbrana kritičnih tačaka ili ofanzivno protivdejstvo. Predviđalo se i aktivno dejstvo gerilskih odreda koji bi posle povlačenja glavnih snaga ostajali u neprijateljskoj pozadini. S obzirom na definisane neprijatelje, dejstva prema Bugarskoj nisu bila predviđena izuzev osmatranja koje bi vršile 2. konjička divizija, na prostoru između Bele Palanke i Pirota, i 2. konjička brigada, u rejonu Štipa i Kočana. Na osnovu ovog plana jasno je da Bugarska nije uzeta u obzir kao neprijatelj u budućem ratu, pošto je najvažnija komunikacija i veza sa Solunom ostala gotovo neobezbeđena. U slučaju eventualnog bugarskog napada jugoslovenski generalštab je računao na pomoć zemalja potpisnica Balkanskog pakta i njihovim armijama ostavljao je glavnu ulogu u rešavanju rata na istoku.

Sledeći ratni plan pod nazivom „R-40“ usvojen je ubrzo posle plana „S“ i smenjivanja generala Simovića sa funkcije. Izmene koje je doneo novi plan odnosile su se na smanjenje strategijske rezerve na račun čega je ojačan front prema istoku. Granicu prema Bugarskoj obezbeđivale bi jedinice $\mathrm{V}$ armije svrstane $\mathrm{u}$ četiri pešadijske i jednu konjičku diviziju. Redukovana strategijska rezerva delila se na dve grupe: VI armiju, smeštenu na prostoru od Iloka do Rače i četiri samostalne pešadijske divizije kod Zagreba, Pakraca, Niša i Skoplja. ${ }^{34}$ Ratni plan „R-40" uskoro se pokazao neadekvatnim pošto je u proleće 1940. godine Francuska poražena u ratu, Mađarska i Rumunija prišle Trojnom paktu, a Italija napala Grčku. Međutim, jugoslovenski generalštab je odlagao donošenje novog plana sve do februara 1941. kada je izrađen „R-41" - poslednji u nizu ratnih planova Vojske Kraljevine Jugoslavije.

Plan „R-41“ je bio prepravljeni „R-40“, s tim što su pojedini momenti (ulazak nemačkih trupa u Rumuniju, pristupanje Bugarske Trojnom paktu) nalagali izmene u odnosu na istočni front. Osnovna ideja plana bila je odbrana na drugim frontovima, osim prema Albaniji, radi zadržavanja neprijatelja. Ofanziva prema Albaniji planirana je da bi se što pre uspostavila veza sa grčkim trupama i omogućio prolaz jugoslovenskih snaga preko albanske teritorije. Pod neprijateljskim pritiskom povlačilo bi se na jug, prema Grčkoj gde bi se organizovao novi front zajedno sa grčkom i engle-

${ }^{34}$ V. Terzić, Jugoslavija u Aprilskom ratu 1941, Titograd 1963, 311-314; D. Tešić, n. $\check{c}, 45-51$. 
Niška oblast i moravsko-vardarski pravac u strategijskim zamislima i ratnim planovima... 59

skom vojskom. U tom cilju pojačan je i granični front prema Bugarskoj kako bi se sprečilo presecanje odstupnice glavnim snagama prilikom povlačenja. Severni deo granice prema Bugarskoj obezbeđivala je samostalna V armija sa Krajinskom (Zaječar), Timočkom (Knjaževac) i Topličkom divizijom (Pirot) i dva odreda: Vlasinskim i Svetonikolskim. U armijskoj rezervi nalazila se Drinska divizija u rejonu Leskovca. Prema južnoj granici sa $\mathrm{Bu}$ garskom nalazile su se trupe III armijske oblasti: Bregalnička (Štip), Moravska (Kriva Palanka) i Šumadijska divizija (Gradsko). ${ }^{35}$

Poslednji ratni plan je, kako se ubrzo ispostavilo, donet sa zakašnjenjem. U februaru 1941, kada je osmišljen, nemačke snage još uvek nisu ušle u Bugarsku, tako da se ideja o uspešnoj odbrani istočne granice raspršila već pri prvom udaru nemačke XII armije. Pregovori vođeni sa Grcima i Englezima nisu urodili plodom zbog malobrojnih snaga kojima je na ovoj teritoriji raspolagala komanda za Bliski istok, a posle nemačkog munjevitog napada prekinute su veze između saveznika i jugoslovenskoj vojsci onemogućeno odstupanje na jug.

\section{Utvrđivanje}

Shodno defanzivnoj strategiji detaljno obrađenoj u ratnim planovima, jugoslovenski generalštab je 1930-ih godina preduzeo opsežne mere utvrđivanja radi zatvaranja osetljivih pravaca eventualnog neprijateljskog prodora. Utvrđivanjem je trebalo nadomestiti nedostatak savremenih sredstava za vođenje rata i omogućiti jedinicama u pozadini fronta, pre svega, lakšu mobilizaciju i koncentraciju, a zatim i manevrisanje, s obzirom na sumnjivo držanje većine suseda. Prema planu, prvi radovi na utvrđivanju izvršeni su na granici prema Italiji, kao najopasnijem protivniku, a zatim i Austriji i Mađarskoj, da bi se istočne granice uzele u obzir tek 1940. godine, kada su nemačke snage ušle u Rumuniju. Iako su raniji ratni planovi (naročito za rat sa Italijom) predviđali zatvaranje nekoliko osetljivih prelaza iz pravca Bugarske, značajniji radovi preduzeti su tek pred početak rata u skladu sa osnovnom idejom povlačenja vojske na jug. Delimično je izvršeno zaprečavanje u dolini Timoka kod Knjaževca, Zaječara i Negotina i na pravcima Pirota Trna, Bosiljgrada, Krive Palanke, Carevog sela i Strumice. U izgradnji su bili protivtenkovski rovovi i betonski bunkeri, dok žičane prepreke nisu bile postavljene u trenutku izbijanja Aprilskog rata. ${ }^{36}$ Ispostavilo se u ratu da su solidna granična utvrđenja sa manjim i većim bunkerima, protivtenkovskim preprekama i osmatračnicama na severozapadnom frontu bila beskorisna, dok ih na granici prema Bugarskoj nije bilo iako su tamo

\footnotetext{
${ }^{35}$ VA, P 17, K 3a, F 1, 1, 1-33. Plan „R-41“.

${ }^{36}$ V. Terzić, $n$. d., 307.
} 
bila najpotrebnija prema ideji ratnog plana „R-41“ kako bi osigurala odstupnicu vojsci prilikom povlačenja u Grčku. Malo pažnje na bugarskoj granici posvećeno je i zaprečavanju, a delimična rušenja nisu dala vidnije rezultate prilikom brzog prodora nemačkih oklopnih i mehanizovanih jedinica. ${ }^{37}$

Utvrđivanje najosetljivijeg dela fronta prema Bugarskoj, doline reke Nišave, izvedeno je po dubini od same granice do Pirota koji je trebalo obezbediti od napada direktno iz pravca Caribroda i indirektno iz pravca Kalne preko Svrljiških planina, što bi preseklo komunikaciju Niš-Pirot. Sistem utvrđenja oko Pirota je na dominantnim tačkama predviđao smeštaj streljačkih četa uz dodatak topova koje je po ratnoj formaciju obezbeđivao 26. artiljerijski puk. Primer je utvrđenje „Crni Vrh“, severoistočno od grada, na kome je izgrađena karaula još 1893. godine, preuređeno za smeštaj streljačke čete sa uređenim grudobranima za devet brdskih topova. Sa ovog utvrđenja kontrolisana je teritorija na severu od reke Visočice, pritoke Nišave, do pruge i puta Pirot-Caribrod, na jugu. Sa desne strane pruge prema Caribrodu nalazila su se utvrđenja "Nišavska dolina“, „Božurato" i „Jarčar" koja su, pored kontrole ove komunikacije, obezbeđivala i selo Sukovo u čijoj blizini se prema potrebi mogao obrazovati pomoćni aerodrom za potrebe 5. lovačkog puka. Pravac iz Bele Palanke obezbeđen je utvrđenjem „Momčilovac“, dok se blizu Babušnice nalazilo utvrđenje „Jeremija“. ${ }^{38}$ Posade ovih utvrđenja činili su obveznici rezervne vojske (od 40 do 50 godina) svrstani u posadne i rezervne pukove. Mobilisani su sa teritorije Pirota i okoline kako bi u najkraćem roku (najduže 24 časa) mogli da se jave na dužnost. Pri mobilizaciji u posadne pukove izbegavalo se raspoređivanje pripadnika nacionalnih manjina, u ovom slučaju Bugara. ${ }^{39}$

Prilikom pregleda utvrđivanja nišavskog pravca, februara 1940, komisija generalštaba je na ovom odseku našla više nedostataka koji nisu otklonjeni do početka rata. Pre svega, na pravcu Trn-Svođ nije izvršeno potpuno zatvaranje i stvoreni su veliki međuprostori koji su na ispresecanom i pošumljenom zemljištu dozvoljavali iznenađenja priređena od manjih snaga. Na pravcu Pirot-Caribrod nisu zaposednute glavne tačke sa kojih bi neprijatelj mogao ugroziti ovu komunikaciju. Zatim je preporučena izrada zaklona od betona umesto drveta, zbog opasnosti krađe od strane lokalnog stanovništva koje je oskudevalo u drvnoj građi. Na kraju je predviđeno i zaprečavanje u vidu plavljenja Nišave i njenih pritoka, pošto su komunikacije uglavnom vodile dolinama reka. ${ }^{40}$ Što se samih utvrđenja tiče Stalna

\footnotetext{
${ }^{37}$ Isto, 308-309.

${ }^{38}$ VA, P 17, K 574, F 1, 11, 2-8. Opšti pregled pirotskih utvrđenja i pojedinačne skice.

${ }^{39} \mathrm{~V}$. Terzić, $n$. d., 331.

${ }^{40}$ VA, P 17, K 464, F 1, 1, 1-11. Izveštaj komisije načelniku generalštaba Str. Pov.
} Br. 65 od 20. februara 1940. 
Niška oblast i moravsko-vardarski pravac u strategijskim zamislima i ratnim planovima ... 61

komisija za utvrđivanje iznela je primedbu o postavljanju oruđa koja nisu dovoljno zaklonjena niti maskirana, tako da predstavljaju odličnu metu avijaciji. Na pojedinim osloncima automatska oruđa su nagomilana, čitavi vodovi, na relativno malom prostoru, dok ih na drugim nema dovoljno. Pojedine linije predviđale su dvostepenu mitraljesku vatru i planirale oruđa $u$ dve linije, što je bilo necelishodno i direktno štetilo odbrani glavne borbene linije, s obzirom na mali broj mitraljeza. Komisija u planu nije primetila fortifikacijske organizacije za četne i bataljonske rezerve, što je značilo da glavna borbena linija nije bila uređena po dubini. U pogledu predviđenog zaprečavanja komisija je navela kao neadekvatne prokope po širini puta, jer zahtevaju obiman rad, vreme i radnu snagu, a što je najvažnije, ne predstavljaju prepreku za neprijateljske tenkove i ne mogu se pripremati u vreme mira. U tom bi slučaju najcelishodnija bila upotreba železničkih šina, ranije postavljenih blizu komunikacija, ili priprema rušenja na pojedinim pogodnim mestima. Odbačena je i ideja o postavljanju barikada od lomljenog kamenja na putevima, jer bi se one mogle izraditi tek $u$ trenutku potrebe. $S$ tim u vezi, skrenuta je pažnja na nepoznavanje termina „zaprečavanje“ i njegovo poistovećivanje sa rušenjem. Dalje primedbe iznete su na nedovoljan broj manjih utvrđenja i navedene su važne nezaštićene tačke koje bi trebalo osigurati. ${ }^{41}$

Utvrđivanje granice sa Bugarskom nije završeno do izbijanja Aprilskog rata. Prema naređenju, štab utvrđivanja zajedno sa svojim štabovima odseka prestao bi sa radom u slučaju mobilizacije, a svo ljudstvo bi bilo raspoređeno u svoje ratne jedinice. ${ }^{42}$ Sami radovi na pojedinim odsecima nastavljeni su i posle mobilizacije, ali su nedovoljno utvrđeni pravci morali biti hitno posednuti delovima operativnih jedinica kao pojačanje posadnim pukovima.

${ }^{41}$ VA, P 17, K 450, F 2, 10, 3-6. Izveštaj Stalne komisije za utvrđivanje načelniku generalštaba Str. Pov. Br. 553 od 18. marta 1940.

${ }^{42}$ VA, P 17, K 891, F 2a, 53, 6-7. Štab konjice komandantu 2. konjičke divizije Str. Pov. Đ. Br. 4235 od 10. oktobra 1940. dostavlja naređenje ministra vojnog o prestanku dejstva štaba utvrđivanja. 
Dalibor Velojić

THE REGION OF NIŠ AND THE MORAVA-VARDAR ROUTE
IN STRATEGIC CONCEPTION AND MILITARY PLANS
OF THE YUGOSLAV MILITARY LEADERSHIP 1918-1941

Summary

Niš, as the crossroads of ways and the city with a very sensitive position, presented for Serbian state a very important military centre towards Bulgaria in the east and Turkey in the west. After the end of the First World War and following the union, together with Skoplje, it undertook the task of defending the eastern border of the newly established state. Its strategic importance can be best taken into account from military plans made by Yugoslav general headquarters in the period between two world wars. The basic conception of those military plans pointed at defense of the main route, spreading along the valley of the river Nišava, as well as supporting valleys of the rivers Timok and Vlasina. On the basis of these plans, the intention of the Yugoslav military leadership to position a strong garnison in Niš, seemed justified. 